\title{
KOMPETENSI IPA TERINTEGRASI MELALUI PENDEKATAN KETERAMPILAN PROSES MAHASISWA S-1 PENDIDIKAN IPA
}

\author{
Insih Wilujeng, Agus Setiawan, dan Liliasari \\ FMIPA Universitas Negeri Yogyakarta dan Sekolah Pascasarjana \\ Universitas Pendidikan Indonesia (e-mail: insihuny@yahoo.co.id; HP 08122741662)
}

\begin{abstract}
Science Education Undergraduate Students' Competence in Integrated Science through the Process Skills Approach. This study aimed to describe the competence of science education undergraduate students, in terms of subject matter competence and pedagogic competence in integrated science using the process skills approach. This study was a descriptive study involving 31 semester VI undergraduate students of science education. The data were collected using the integrated science I test instrument and the integrated science II test instrument; the competence map development assesment instrument and integrated science learning syllabus; and the lesson plan assessment instrument and peer teaching instrument. The results showed increases in the subject matter competence, science interdisciplinary understanding competence for objective questions, and science interdisciplinary understanding competence for essay questions. Students' pedagogic competence in planning integrated science learning ranged from the good category to the very good category, their competence in lesson plan development was good, and their competence in doing and managing learning was fairly good.
\end{abstract}

Keywords : subject matter competence, pedagogic comptetence, integrated science, process skill approach

\section{PENDAHULUAN}

Standards for Science Teacher Preparation (NSTA, 2003:8) merekomendasikan agar guru-guru IPA sekolah dasar dan menengah harus memiliki kecenderungan interdisipliner pada IPA. Sebagai usaha untuk memenuhi tuntutan tersebut, maka guru-guru IPA sekolah dasar dan menengah hendaknya disiapkan untuk memiliki kompetensi dalam biologi, kimia, fisika, bumi dan antariksa serta bidang IPA lainnya.

Program Studi Pendidikan IPA jenjang $\mathrm{S}_{1}$, FMIPA UNY yang dibuka sejak
Tahun Akademik 2007/2008 memiliki tujuan menghasilkan tenaga pendidik dan kependidikan dengan gelar Sarjana Pendidikan Sains bidang keahlian Pendidikan IPA (S.Pd., Si.) memiliki kompetensi dasar tenaga pendidik bidang IPA, yaitu kompetensi pedagogik, kompetensi kepribadian, kompetensi profesional, dan kompetensi sosial. Penjelasan rinci kompetensi-kompetensi dasar adalah sebagai berikut.

Kompetensi pendidikan bidang IPA, yaitu kompetensi melakukan penelitian dalam rangka mengembangkan 
pendidikan IPA, serta kompetensi melakukan penyebaran bidang pendidikan IPA melalui pendidikan dan pelatihan (diklat).

Kompetensi menghadapi masa depan, yaitu kompetensi menghadapi dan memahami kecenderungan pendidikan IPA, serta memanfaatkan hal tersebut untuk memajukan pendidikan IPA.

Kompetensi dasar-dasar IPA dan rumpun IPA yang cukup untuk studi lanjut. (Kurikulum 2002, FMIPA Universitas Negeri Yogyakarta, 2007:5859)

Pusat kurikulum, Balitbang Depdiknas telah menyusun panduan pengembangan pembelajaran IPA terpadu sejak tahun 2005. Namun, kenyataan di lapangan hampir semua guru IPA SMP masih belum menerapkan pembelajaran IPA terpadu tersebut dengan berbagai alasan. Hasil isian angket dari guruguru IPA SMPMTs tahun 2009 di wilayah Yogyakarta meliputi 4 wilayah kabupaten dan 1 wilayah kota dengan sampel 20 orang guru IPA SMP dapat ditemukan beberapa alasan belum dilaksanakannya pembelajaran IPA terpadu. Alasan tersebut antara lain adanya ketakutan para guru tentang muatan materi kurikulum tidak tersampaikan; tidak adanya contoh-contoh pembelajaran IPA terintegrasi/PA terpadu di beberapa buku teks serta belum diperolehnya langkah-langkah pengembangan pembelajaran IPA terintegrasi/ IPA terpadu bagi guru SMP. Pemahaman guru tentang IPA terpadu pun ternyata masih banyak yang mengalami kesalahan secara konsep. Hasil wawancara dengan para guru IPA pada saat pelaksanaan Bimbingan Teknis IPA Terpadu yang diadakan oleh Direktorat Jenderal Manajemen Pendidikan Dasar dan Menengah di Bogor pada tanggal 912 Agustus 2009 dan di Yogyakarta pada tanggal 13-16 Agustus 2009 terbukti bahwa IPA terpadu dipahami sebagai gabungan antara bidang-bidang IPA (gabungan materi fisika, kimia dan biologi). Selain itu, IPA terpadu dipahami bahwa keterpaduan terletak pada gabungan para guru dengan latar belakang pendidikan IPA yang berbeda (guru berlatar belakang pendidikan biologi, pendidikan fisika dan pendidikan kimia).

Subali, dkk. (2005:261) menjelaskan bahwa sosok IPA atau Pengetahuan Alam betul-betul harus ditinjau dari dimensi objek, tingkat organisasi dan persoalan yang ada di dalamnya. Dimensi objek meliputi benda dalam bentuk yang sangat besar/kompleks dan benda yang tidak kasat mata dalam bentuk yang paling kecil. Objek alam juga dapat dibedakan menjadi benda yang hidup dan yang tak hidup. Sosok IPA inilah yang semestinya dipahami oleh para guru di lapangan.

Pada kenyataannya, kondisi di lapangan menunjukkan pemahaman sosok IPA masih belum sesuai yang diharapkan, maka FMIPA UNY yang sejak Tahun Akademik 2007/2008 telah membuka Program Studi Pendidikan IPA $S_{1}$, dituntut untuk merespon dan menindaklanjuti kebijakan pemerintah, terutama Balitbang Depdiknas tentang pembelajaran IPA terpadu yang secara nyata dituntut untuk mempersiapkan mahasiswa sebagai calon guru IPA SMPMTs agar memiliki kompetensi 
dalam IPA terintegrasi dan memiliki pemahaman IPA dalam arti sebenarnya. Bentuk persiapan dituangkan dalam pengembangan program perkuliahan IPA terintegrasi dan pembelajarannya atau FMIPA UNY perlu mensikapi secara positip pemutakhiran kurikulum yang semakin dinamis, agar pembelajaran di Program Studi Pendidikan IPA tidak stagnan atau out of date (Ghufron, 2007: 105).

Mata kuliah teori IPA terintegrasi dan pembelajarannya memiliki tujuan mengembangkan kompetensi mahasiswa dalam menguasai interdisipliner bidang IPA dan memiliki kemampuan serta keterampilan merencanakan kegiatan pembelajaran IPA terintegrasi sesuai standar Kurikulum SMPMTs, sedangkan mata kuliah praktik IPA terintegrasi dan pembelajarannya memiliki tujuan mengembangkan kemampuan mahasiswa dalam melaksanakan, mengelola maupun mengevaluasi kegiatan pembelajaran IPA terintegrasi sesuai standar Kurikulum SMP/MTs. Mata kuliah ini diberikan pada mahasiswa $S_{1}$ pendidikan IPA semester 6 yang merupakan mahasiswa angkatan pertama dari program studi pendidikan IPA di FMIPA Universitas Negeri Yogyakarta.

Standar pembelajaran IPA mengisyaratkan, bahwa aktivitas dalam pembelajaran IPA harus dilengkapi aktivitas berpikir kritis dan kreatif dan tidak membatasi pada rutinitas atau belajar hafalan. Siswa harus dibuat sadar pada keterampilan-keterampilan berpikir dan strategi-strategi berpikir yang mereka gunakan dalam pembelajaran mereka. Mereka harus ditantang dengan pertanyaan dan masalah tingkat tinggi dan perlu untuk memecahkan masalah dengan memanfaatkan berpikir kreatif dan kritis. Proses pembelajaran IPA harus membuat siswa memperoleh pengetahuan, ketuntasan keterampilan dan pengembangan sikap ilmiah dan nilainilai mulia dalam cara terintegrasi. Untuk merealisasikan pembelajaran IPA yang sesuai hakikat IPA, salah satunya adalah dengan pendekatan keterampilan proses dengan model pembelajaran berdasar masalah. Hasil penelitian ( $\mathrm{Su}-$ yono, 2007:253) menunjukkan, bahwa penerapan model pembelajaran berdasar masalah (PBM) secara umum mampu memperbaiki kesulitan siswa dalam menyelesaikan soal-soal berciri keterampilan proses meliputi: merumuskan masalah, merumuskan tujuan percobaan, mengidentifikasi variabel percobaan, merumuskan hipotesis, membuat prediksi, membaca data dan membuat interpretasi serta menarik kesimpulan.

Keterampilan-keterampilan proses sains adalah dasar pemecahan masalah dalam sains dan metode ilmiah. Keterampilan-ketrampilan proses sains dibedakan menjadi dua bagian, yaitu keterampilan dasar proses IPA dan keterampilan terpadu proses IPA. Enam keterampilan dasar proses IPA untuk (K12) mencakup 1) observasi (observing), yaitu menggunakan lima indera untuk menemukan informasi tentang karakteristikbenda, sifatsuatubenda, kesamaankesamaan benda dan ciri-ciri identifikasi lainnya; 2) klasifikasi (classifying), yaitu proses pengelompokan dan pengurutan benda-benda; 3) pengukuran (measuring), yaitu membandingkan kuantitas yang tidak diketahui dengan kuantitas yang diketahui, seperti satuan 
pengukuran standar dan non standar; 4) komunikasi (communicating), yaitu menggunakan multimedia, menulis, membuat grafik atau kegiatan-kegiatan untuk sharing penemuan; 5) inferensi (inferring), yaitu pembentukan ide-ide untuk menjelaskan pengamatan; 6) prediksi (predicting), pengembangan asumsi dari hasil yang diharapkan. Lima keterampilan terpadu proses sains mencakup 1) merumuskan hipotesis (formulating a hypothesis), yaitu membuat suatu prediksi yang didasarkan pada buktibukti penelitian dan penyelidikan sebelumnya; 2) variabel-variabel (variables), yaitu menamai dan mengontrol variabel-variabel bebas (independent), terikat (dependent) dan kontrol (control); 3) difinisi operasional (operational definitions), yaitu mengembangkan istilah-istilah khusus untuk mendeskripsikan apa yang terjadi dalam penyelidikan didasarkan pada karakeristik-karakteristik yang dapat diamati; 4) eksperimen (experimenting), yaitu melakukan suatu penyelidikan; 5) interpretasi data (interpreting data), yaitu menganalisis hasil suatu penyelidikan (Curriculum Development Center, 2002:12).

\section{METODE}

Metode yang digunakan dalam penelitian ini adalah metode deskriptif. Data yang terkumpul dianalisis dan diinterpretasikan, kemudian dideskripsikan untuk menggambarkan kondisi yang terjadi pada subjek penelitian. Penelitian dilakukan di program studi $S_{1}$ pendidikan IPA kelas A, semester VI, FMIPA Universitas Negeri Yogyakarta dengan jumlah subjek penelitian 31 mahasiswa.
Untuk memperoleh data penelitian ini digunakan empat instrumen, meliputi Instrumen 1a, yaitu instrumen tes IPA terintegrasi I (integrasi IPA dengan metode ilmiah) dan Instrumen $1 b$, yaitu instrumen tentang tes pemahaman konsep IPA terintegrasi (tes bentuk obyektif dan subyektif); Instrumen 2, yaitu penilaian pengembangan peta kompetensi dan silabus IPA terintegrasi; Instrumen 3, yaitu penilaian RPP; dan Instrumen 4, yaitu penilaian peer teaching.

Peta kompetensi materi dianalisis dari hasil pengembangan silabus IPA Terintegrasi dari mahasiswa, sedangkan peta kompetensi pedagogi dianalisis dari hasil pengembangan silabus IPA Terintegrasi dan RPP dari mahasiswa. Mengacu dari silabus dan RPP, maka dapat ditetapkan hal-hal yang terkait pedagogi, meliputi analisis sintak keterampilan dasar proses IPA dan keterampilan terpadu proses IPA, metode pembelajaran, asesmen pembelajaran, keterampilan berpikir serta strategi berpikir.

\section{HASIL PENELITIAN KOMPETENSI PEMAHAMAN IPA TERINTEGRASI}

Berdasarkan analisis data hasil penelitian dari Instrumen $1 \mathrm{a}$ dan $1 \mathrm{~b}$ diperoleh hasil, bahwa kompetensi integrasi IPA dengan metode ilmiah mahasiswa $S_{1}$ pendidikan IPA FMIPA UNY diperoleh skor rata-rata tes awal 64,02 dan skor rata-rata tes akhir 91,80 dengan N-gain 0,80. Kompetensi integrasi interdisipliner bidang IPA untuk tema Penjernihan Air khusus soal obyektif diperoleh skor rata-rata tes awal 55,91 dan skor rata-rata tes akhir 94,55 de- 
ngan N-gain 0,88; untuk soal subyektif diperoleh skor rata-rata tes awal 32,78 dan skor rata-rata tes akhir 80,56 dengan N-gain 0,71. Deskripsi kompetensi tes IPA terintegrasi dapat dilihat pada Gambar 1.

Dari 13 tujuan perkuliahan khusus (TPK) untuk integrasi IPA dengan metode ilmiah keseluruhan tuntas dicapai mahasiswa (dengan batas ketuntasan 70\% mahasiswa menjawab benar), namun terdapat tiga TPK kurang dari 75\% mahasiswa menjawab benar, yaitu TPK tentang 1) diberikan deskripsi variabel secara verbal, mahasiswa menyeleksi difinisi operasional variabel; 2) diberikan suatu masalah dengan variabel ter- ikat spesifik, mahasiswa mengidentifikasi hipotesis yang bisa diuji; 3) diberikan suatu hipotesis, mahasiswa memilih rancangan penyelidikan yang memungkinkan untuk menguji hipotesis tersebut. Kompetensi interdisipliner bidang IPA meliputi kompetensi tentang sifat-sifat zat berdasarkan wujudnya dan penerapannya dalam kehidupan sehari-hari 95,8\% mahasiswa menjawab benar, kompetensi tentang pemisahan campuran dengan berbagai cara berdasarkan sifat fisika dan sifat kimia 93,3\% mahasiswa menjawab benar, kompetensi tentang klasifikasikan makhluk hidup berdasarkan ciri-ciri yang dimiliki 91,7\% mahasiswa menjawab benar.



Gambar 1. Grafik Skor Tes Awal dan Tes Akhir IPA Terintegrasi I



Gambar 2a. Grafik Persentase Mahasiswa Menjawab Benar setiap Tujuan Perkuliahan Khusus (TPK) 


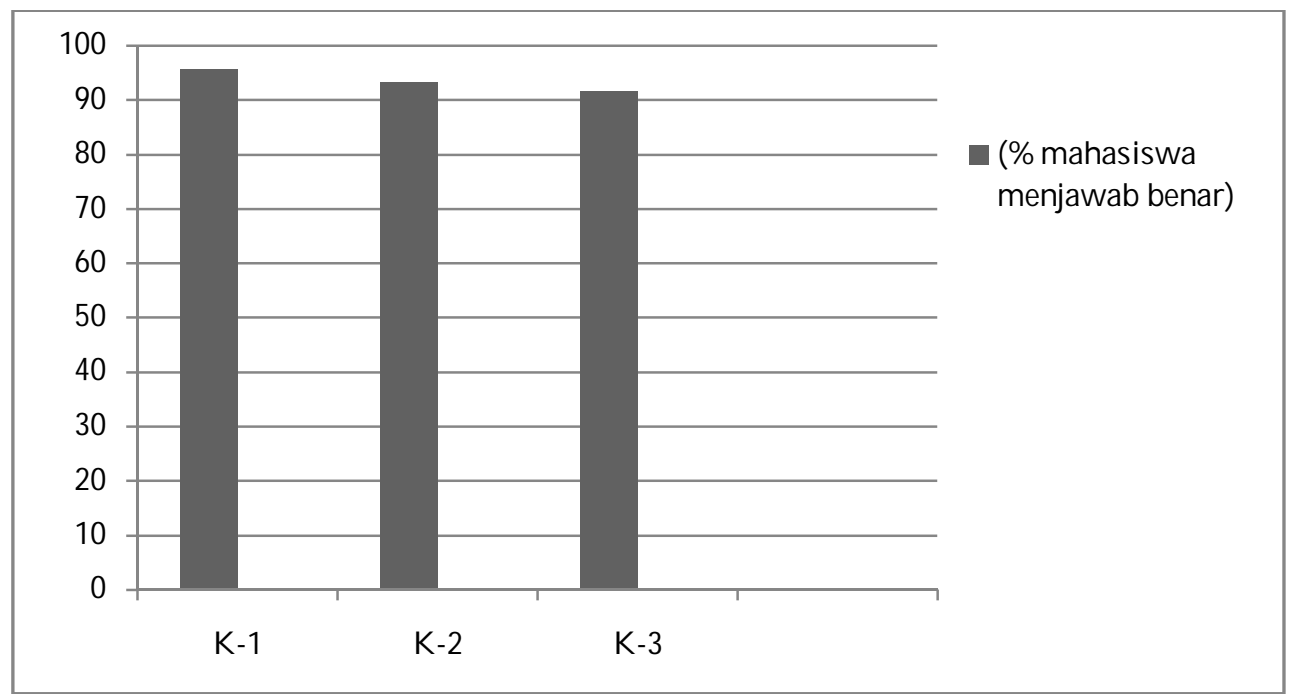

Gambar 2b. Grafik Persentasi Mahasiswa Menjawab Benar Setiap Kompetensi

Materi

Keterangan:

K-1 : Sifat-sifat zat berdasarkan wujudnya dan penerapannya dalam kehidupan sehari-hari

K-2 : Pemisahan campuran dengan berbagai cara berdasarkan sifat fisika dan sifat kimia

K-3 : Klasifikasikan makhluk hidup berdasarkan ciri-ciri yang dimiliki

Gambar 2a dan 2b di atas menunjukkan persentasi mahasiswa menjawab benar setiap tujuan perkuliahan khusus dan setiap bidang interdisipliner.

PETA KOMPETENSI DAN SILABUS IPA TERINTEGRASI

Kompetensi mahasiswa dalam mengembangkan peta kompetensi dan si- labus dinilai dengan Instrumen 2 (penilaian peta kompetensi dan silabus IPA terintegrasi). Aspek-aspek yang dinilai untuk peta kompetensi meliputi: pemetaan IPA terintegrasi, tema, analisis isi dan proses; sedangkan untuk silabus aspek yang dinilai meliputi: identitas silabus pembelajaran IPA terintegrasi, isi utama silabus (tujuan, indikator, materi dan kegiatan pembelajaran), isi pendukung silabus (teknik asesmen, bentuk instrumen, alokasi waktu dan sumber belajar).

Deskripsikompetensimahasiswa dalam mengembangkan peta kompetensi dan silabus dapat dilihat pada Gambar 3. 


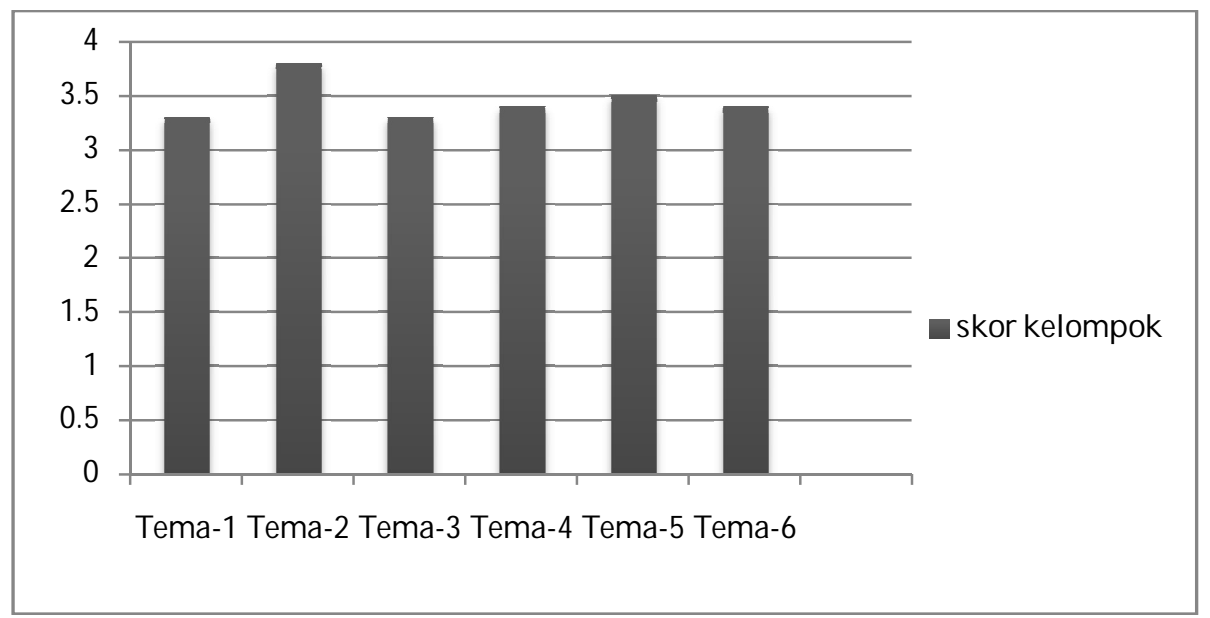

Gambar 3. Grafik Skor Kelompok Mahasiswa dalam Mengembangkan

Peta Kompetensi dan Silabus

\section{Keterangan :}

Skor 1 = kurang; skor 2 = cukup; skor 3 =baik; dan skor 4 = sangat baik

Setiap skor memiliki kriteria masingmasing.

Tema-1: Transformasi Tumbuhan; Tema-2 : Makanan dan Tubuhku; Tema3 : Udara Sehat; Tema-4: Kulit Tubuhku; Tema-5: Hijaunya daun-daun; dan Tema-6 : Pentingnya Makan.

Rata-rata skor mahasiswa dalam mengembangkan peta kompetensi dan silabus pembelajaran IPA terintegrasi adalah 3,5 (baik sampai sangat baik)

\section{PENGEMBANGKAN RPP}

Kompetensi mahasiswa dalam mengembangkan RPP dinilai dengan Instrumen 3 (penilaian RPP). Aspek-aspek yang dinilai dalam pengembangan RPP meliputi: identitas RPP, perumusan tujuan dan indikator pembelajaran, materi pembelajaran, metode dan strategi pembelajaran, langkah-langkah kegiatan pembelajaran, sumber belajar, dan asesmen.

Deskripsi kompetensi mahasiswa dalam mengembangkan RPP dapat dilihat pada Gambar 4.

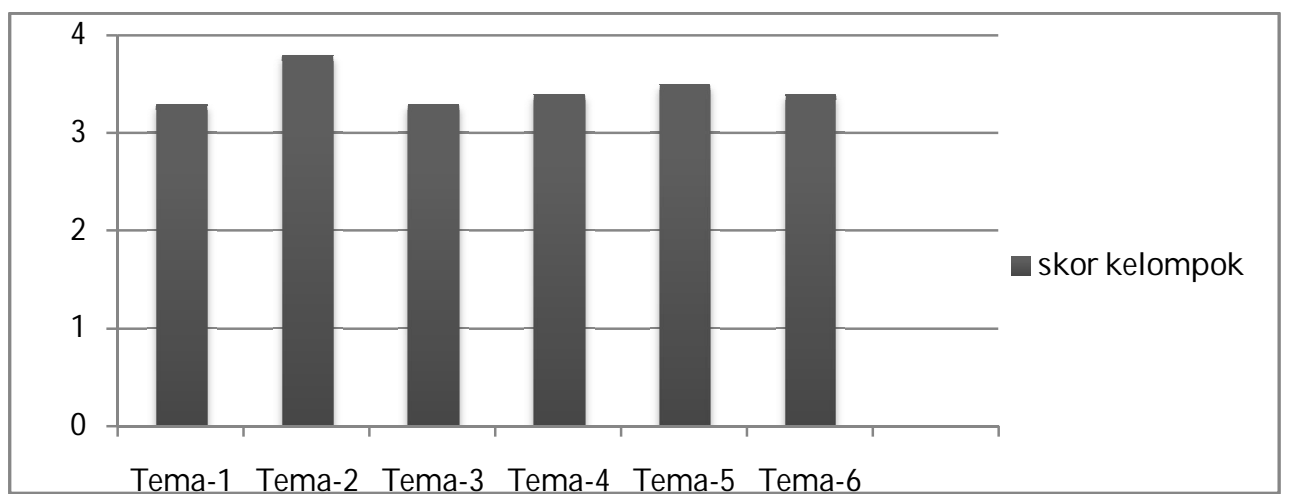

Gambar 4. Grafik Skor Kelompok Mahasiswa dalam Mengembangkan RPP 
Keterangan:

Skor 1 = kurang; skor 2 = cukup; skor 3 =baik dan skor 4 = sangat baik

Setiap skore memiliki kriteria masingmasing.

Tema-1 : Transformasi Tumbuhan; Tema-2 : Makanan dan Tubuhku, Tema3 : Udara Sehat; Tema-4: Kulit Tubuhku; Tema-5 : Hijaunya daun-daun; dan Tema-6 : Pentingnya Makan. Rata-rata skor mahasiswa dalam mengembangkan RPP adalah 3,1 (baik).

\section{KOMPETENSI PEER TEACHING}

Kompetensi mahasiswa dalam peer teaching dinilai dengan Instrumen 4 (penilaian peer teaching). Aspek-aspek yang dinilai untuk peer teaching meliputi: bagian pendahuluan (pemotivasian siswa, apersepsi dan penyampaian tujuan); bagian kegiatan inti (pengorganisasian siswa dalam pembelajaran, bimbingan padasiswa, keruntutan pembelajaran, penciptaan peluang siswa belajar aktif, pelaksanaan penilaian proses, pemberian umpan balik; bagian penutup (kesimpulan materi, pemantapan); dan lainlain (penguasaan materi, kesesuain pembelajaran dengan $\mathrm{KD}$, mengimplementasikan pembelajaran IPA terintegrasi, mengimplementasikan prinsip-prinsip PKP, dan penggunaan sumber belajar dan media).

Deskripsi kompetensi mahasiswa dalam pelaksanaan peer teaching dapat dilihat pada Gambar 5.

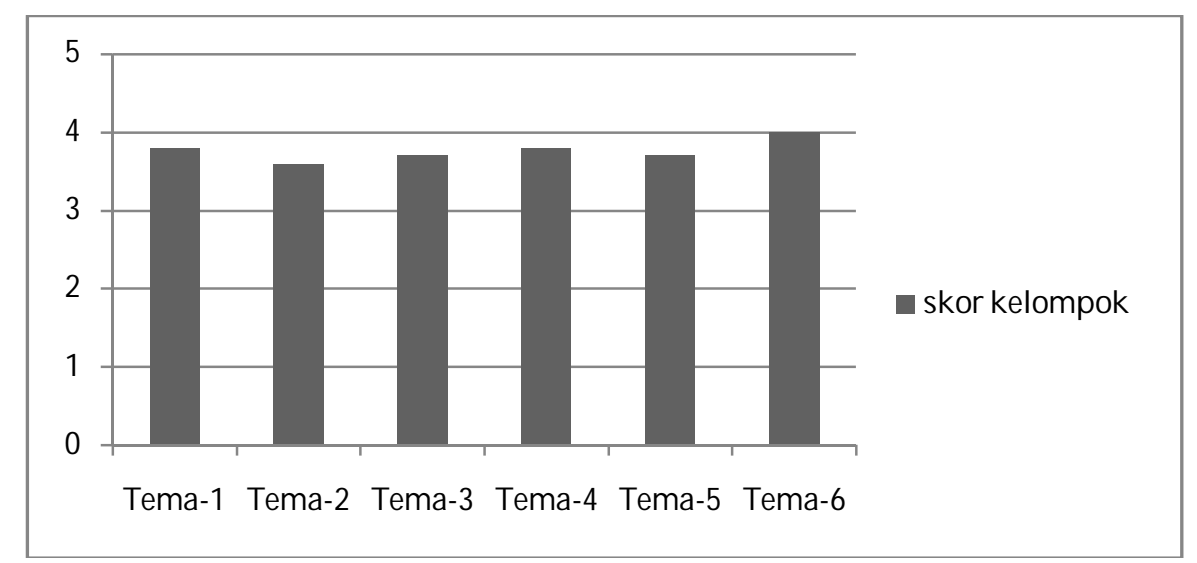

Gambar 5. Grafik Skor Kelompok Mahasiswa dalam Pelaksanaan Peer Teaching

\section{Keterangan:}

Skor 1 = sangat tidak baik; skor $2=$ tidak baik; skor $3=$ kurang baik, skor 4 $=$ baik dan skor $5=$ sangat baik. Setiap skor memiliki kriteria masing-masing.

Tema-1 : Transformasi Tumbuhan; Tema-2 : Makanan dan Tubuhku; Tema3 : Udara Sehat; Tema-4: Kulit Tubuhku;
Tema-5 : Hijaunya daun-daun; dan Tema-6 : Pentingnya Makan. Rata-rata skor mahasiswa dalam peer teaching adalah 3,8 (mendekati baik). 
ANALISIS PETA KOMPETENSI MATERI DAN PETA KOMPETENSI PE-

\section{DAGOGI}

Peta kompetensi materi dianalisis dari hasil pengembangan silabus IPA Terintegrasi dari mahasiswa. Mengacu dari silabus, maka dapat ditetapkan halhal yang terkait materi, meliputi tujuan pembelajaran, indikator pembelajaran, materi pembelajaran. Hasil analisis materi dapat dideskripsikan dalam Tabel 1.

Tabel 1. Hasil Analisis Materi IPA Terintegrasi dengan PKP

\begin{tabular}{|c|c|c|c|c|}
\hline \multirow{2}{*}{ Tema } & \multicolumn{4}{|c|}{ Kompetensi Bidang IPA } \\
\hline & Biologi & Fisika & Kimia & Bidang lainnya \\
\hline $\begin{array}{l}\text { Transformasi } \\
\text { Tumbuhan }\end{array}$ & $\begin{array}{l}\text { Struktur dan } \\
\text { Fungsi Jaringan } \\
\text { pada Tumbuhan } \\
\text { (Jaringan } \\
\text { transportasi) }\end{array}$ & $\begin{array}{l}\text { Massa jenis } \\
\text { (kerapatan) zat } \\
\text { dan daya } \\
\text { kapilaritas }\end{array}$ & $\begin{array}{l}\text { Lambang unsur dan } \\
\text { senyawa }\end{array}$ & \\
\hline $\begin{array}{l}\text { Makanan dan } \\
\text { Tubuhku }\end{array}$ & $\begin{array}{l}\text { Uji makanan } \\
\text { (kanji, gula dan } \\
\text { protein) } \\
\text { Sistem } \\
\text { Pencernakan pada } \\
\text { manusia }\end{array}$ & $\begin{array}{l}\text { Perubahan fisika } \\
\text { dan kimia zat }\end{array}$ & $\begin{array}{l}\text { Lambang senyawa } \\
\text { gula, protein, } \\
\text { karbohidrat }\end{array}$ & $\begin{array}{l}\text { Kesehatan } \\
\text { pada alat-alat } \\
\text { pencenakan } \\
\text { (Kesehatan) }\end{array}$ \\
\hline Udara Sehat & $\begin{array}{l}\text { Gas-gas yang } \\
\text { terkait dalam } \\
\text { proses pernapasan } \\
\text { manusia }\end{array}$ & $\begin{array}{l}\text { Hubungan suhu, } \\
\text { volume dan } \\
\text { tekanan udara }\end{array}$ & $\begin{array}{l}\text { Lambang-lambang } \\
\text { senyawa dalam } \\
\text { udara /atmosfer } \\
\text { (lambang gas } \\
\text { oksigen, } \\
\text { karbondioksida, } \\
\text { methana, nitrogen } \\
\text { dan gas-gas lainnya) }\end{array}$ & $\begin{array}{l}\text { Komposisi } \\
\text { atmosfer (Earth } \\
\text { Science) }\end{array}$ \\
\hline Kulit Tubuhku & $\begin{array}{l}\text { Struktur dan } \\
\text { Fungsi Kulit } \\
\text { Respon kulit } \\
\text { terhadap stimulus } \\
\text { tekanan }\end{array}$ & $\begin{array}{l}\text { Tekanan benda } \\
\text { padat }\end{array}$ & $\begin{array}{l}\text { Sifat asam, basa dan } \\
\text { garam suatu larutan } \\
\text { (keringat hasil } \\
\text { ekskresi kulit) }\end{array}$ & $\begin{array}{l}\text { Menjaga } \\
\text { kesehatan kulit } \\
\text { (Kesehatan) }\end{array}$ \\
\hline $\begin{array}{l}\text { Hijaunya } \\
\text { Daun-daun }\end{array}$ & $\begin{array}{l}\text { Fotosintesis pada } \\
\text { tumbuhan }\end{array}$ & $\begin{array}{l}\text { Peran cahaya } \\
\text { dalam proses } \\
\text { fotosntesis }\end{array}$ & $\begin{array}{l}\text { Reaksi Fotosintesis } \\
\text { dan simbul-simbul } \\
\text { senyawa dalam } \\
\text { reaksi fotosintesis }\end{array}$ & $\begin{array}{l}\text { Lingkungan } \\
\text { (Pentingnya } \\
\text { Tamanisasi) }\end{array}$ \\
\hline $\begin{array}{l}\text { Pentingnya } \\
\text { Makan }\end{array}$ & $\begin{array}{l}\text { Proses pencernaan } \\
\text { pada manusia }\end{array}$ & Konversi Energi & $\begin{array}{l}\text { Nutrisi dan } \\
\text { fungsinya }\end{array}$ & \\
\hline
\end{tabular}

Peta kompetensi pedagogi dianalisis dari hasil pengembangan silabus IPA Terintegrasi dan RPP dari mahasiswa. Mengacu dari silabus dan RPP, maka dapat ditetapkan hal-hal yang terkait pedagogi, meliputi pendekatan pembelajaran, metode pembelajaran, dan asesmen pembelajaran, keterampilan berpikir serta strategi berpikir. Hasil analisis pedagogi dapat dideskripsikan dalam Tabel 2. 
Tabel 2. Hasil Analisis Pedagogi IPA Terintegrasi dengan PKP

\begin{tabular}{|c|c|c|c|c|}
\hline Tema & P-K-P & $\begin{array}{c}\text { Metode } \\
\text { Pembelajaran }\end{array}$ & Asesemen & $\begin{array}{c}\text { Keterampilan Berpikir/Strategi } \\
\text { Berpikir }\end{array}$ \\
\hline $\begin{array}{l}\text { Transformasi } \\
\text { Tumbuhan }\end{array}$ & $\begin{array}{l}\text { Observasi, Inferensi } \\
\text { dan Klarifikasi } \\
\text { (Keterampilan } \\
\text { proses dasar) }\end{array}$ & $\begin{array}{l}\text { Demonstrasi, } \\
\text { Eksperimen, } \\
\text { Diskusi, Tanya } \\
\text { jawab dan } \\
\text { Penyelidikan }\end{array}$ & $\begin{array}{l}\text { Tes } \\
\text { tertulis } \\
\text { dan Unjuk } \\
\text { Kerja }\end{array}$ & $\begin{array}{l}\text { Berikir kritis dan kreatif (Meng- } \\
\text { hubungkan, Membandingkan, } \\
\text { Membedakan, dan Mengelom- } \\
\text { pokkan Strategi Berikir (Kon- } \\
\text { septualisasi, Pemecahan } \\
\text { Masalah) }\end{array}$ \\
\hline $\begin{array}{l}\text { Makanan } \\
\text { dan } \\
\text { Tubuhku }\end{array}$ & $\begin{array}{l}\text { Observasi, Klasifika- } \\
\text { si, Komunikasi, (kete- } \\
\text { rampilan proses da- } \\
\text { sar); Melakukan eks- } \\
\text { perimen, Interpretasi } \\
\text { gambar (keteram- } \\
\text { pilan proses lanjut) }\end{array}$ & $\begin{array}{l}\text { Eksperimen, } \\
\text { Demonstrasi, } \\
\text { Diskusi dan } \\
\text { Presentasi } \\
\text { siswa. }\end{array}$ & $\begin{array}{l}\text { Tes } \\
\text { tertulis } \\
\text { uraian } \\
\text { dan Unjuk } \\
\text { Kerja }\end{array}$ & $\begin{array}{l}\text { Keterampilan Berikir : semua } \\
\text { keterampilan berpikir } \\
\text { Strategi Berpikir: } \\
\text { Konseptualisasi, } \\
\text { Membuat Keputusan dan } \\
\text { Pemecahan Masalah }\end{array}$ \\
\hline Udara Sehat & $\begin{array}{l}\text { Observasi, Inferensi } \\
\text { (keterampilan } \\
\text { proses dasar); } \\
\text { Interpretasi grafik } \\
\text { (keterampilan } \\
\text { proses lanjut) }\end{array}$ & $\begin{array}{l}\text { Demonstrasi, } \\
\text { Eksperimen, } \\
\text { Diskusi dan } \\
\text { Studi } \\
\text { referensi. }\end{array}$ & $\begin{array}{l}\text { Tes } \\
\text { tertulis } \\
\text { dan Unjuk } \\
\text { Kerja }\end{array}$ & $\begin{array}{l}\text { Keterampilan } \\
\text { Berpikir:Membandingkan dan } \\
\text { membedakan, Menganalisis, } \\
\text { Mendeteksi bias, Membuat } \\
\text { kesimpulan, Membuat } \\
\text { generalisasi dan Mengevaluasi } \\
\text { Strategi Berpikir: onseptualisasi, } \\
\text { Membuat Keputusan dan Peme- } \\
\text { cahan Masalah }\end{array}$ \\
\hline $\begin{array}{l}\text { Kulit } \\
\text { Tubuhku }\end{array}$ & $\begin{array}{l}\text { Observasi, Komuni- } \\
\text { kasi, Inferensi (Kete- } \\
\text { rampilan proses das- } \\
\text { ar); Pengendalian } \\
\text { variabel (keteram- } \\
\text { pilan proses lanjut) }\end{array}$ & $\begin{array}{l}\text { Eksperimen } \\
\text { dan Studi } \\
\text { referensi }\end{array}$ & $\begin{array}{l}\text { Tes } \\
\text { Tertulis } \\
\text { dan Unjuk } \\
\text { Kerja }\end{array}$ & $\begin{array}{l}\text { Keterampilan Berpikir: } \\
\text { Menghubungkan, } \\
\text { Membandingkan, dan } \\
\text { membedakan, Membuat relasi, } \\
\text { menganalisis } \\
\text { Strategi Berpikir: Konseptualisa- } \\
\text { si dan Membuat Keputusan }\end{array}$ \\
\hline $\begin{array}{l}\text { Hijaunya } \\
\text { Daun }\end{array}$ & $\begin{array}{l}\text { Observasi, } \\
\text { Komunikasi, } \\
\text { Inferensi } \\
\text { (Keterampilan } \\
\text { proses dasar); } \\
\text { Interpretasi gambar } \\
\text { (Keterampilan } \\
\text { proses lanjut) }\end{array}$ & $\begin{array}{l}\text { Diskusi, } \\
\text { Demosntrasi, } \\
\text { Presentasi } \\
\text { siswa, dan } \\
\text { Penayangan } \\
\text { Video }\end{array}$ & $\begin{array}{l}\text { Tes } \\
\text { tertulis } \\
\text { dan Unjuk } \\
\text { Kerja }\end{array}$ & $\begin{array}{l}\text { Keterampilan Berpikir: Mem- } \\
\text { bandingkan dan membedakan, } \\
\text { Menganalisis, Mendeteksi bias } \\
\text { (kerancuan), Membuat kesim- } \\
\text { pulan, Membuat generalisasi } \\
\text { dan Mengevaluasi } \\
\text { Strategi Berpikir: } \\
\text { Konseptualisasi, Mengambil } \\
\text { keputusan dan Pemecahan } \\
\text { Masalah }\end{array}$ \\
\hline $\begin{array}{l}\text { Penting- } \\
\text { nya Makan }\end{array}$ & $\begin{array}{l}\text { Mengurutkan, meng- } \\
\text { komunikasikan, } \\
\text { Observasi, Klasifikasi } \\
\text { (Keterampilan proses } \\
\text { dasar); Melakukan } \\
\text { eksperimen (keteram- } \\
\text { pilan proses lanjut) }\end{array}$ & $\begin{array}{l}\text { Eksperimen, } \\
\text { Diskusi dan } \\
\text { Kaji referensi }\end{array}$ & $\begin{array}{l}\text { Tes } \\
\text { tertulis } \\
\text { dan Unjuk } \\
\text { kerja }\end{array}$ & $\begin{array}{l}\text { Keterampilan Berpikir : semua } \\
\text { jenis keterampilan berpikir } \\
\text { Strategi Berikir: } \\
\text { Konseptualisasi dan Mengambil } \\
\text { Keputusan }\end{array}$ \\
\hline
\end{tabular}




\section{KESIMPULAN}

Dari hasil penelitian dapat disimpulkan, bahwa content competence mahasiswa $S_{1}$ pendidikan IPA tentang integrasi IPA dengan metode ilmiah sudah baik karena terjadi peningkatan kompetensi integrasi IPA dengan metode ilmiah mahasiswa $S_{1}$ pendidikan IPA dengan skor rata-rata tes awal 64,02 dan skor rata-rata tes akhir 91,80 dengan $\mathrm{N}$ gain 0,80 ; terdapat peningkatan kompetensi pemahaman interdisipliner bidang IPA untuk soal objektif dengan skor rata-rata tes awal 55,91 dan skor ratarata tes akhir 94,55 dengan $\mathrm{N}$-gain 0,88; terdapat peningkatan kompetensi pemahaman interdisipliner bidang IPA untuk soal subyektif dengan skor ratarata tes awal 32,78 dan skor rata-rata tes akhir 80,56 dengan N-gain 0,71.

Pedagogy competence mahasiswa dalam merancang dan mengembangkan IPA terintegrasi berkategori baik (skor peta kompetensi dan silabus $=3,5$ serta skor $\mathrm{RPP}=3,1$ untuk rentang skor 1-4), sedangkan kompetensi mahasiswa dalam melaksanakan dan mengelola pembelajaran IPA terintegrasi masih kurang baik (skor peer teaching $=3,8$ untuk rentang skor 1-5). Perangkat IPA Terintegrasi yang dikembangkan oleh mahasiswa $S_{1}$ pendidikan IPA untuk pendekatan keterampilan proses sesudah dilakukan analisis dari segi materi dan pedagogi dapat disimpulkan, bahwa tematema yang dianalisis ada 6 tema besar untuk IPA Terintegrasi dengan pendekatan keterampilan proses dan hasil analisis materi mencakup interdisipliner bidang IPA yang meliputi biologi, fisika, kimia, kesehatan, earth science dan lingkungan; hasil analisis pedagogi mencakup variasi metode pembelajaran, asesmen, keterampilan proses, keterampilan berpikir kritis dan kreatif dan strategi berpikir sesuai keterampilan proses yang muncul.

\section{SARAN}

Berdasar hasil analisis content competence dan pedagogy competence, maka kompetensi IPA terintegrasi mahasiswa $S_{1}$ Pendidikan IPA bisa dikatakan baik, namun peneliti menyarankan bahwa mahasiswa $S_{1}$ Pendidikan IPA tetap perlu dibekali mata kuliah IPA terintegrasi dan pembelajarannya melalui pendekatan-pendekatan lain seperti sainsteknologi-masyarakat dan inkuiri. Hal itu perlu dilakukan karena pendekatanpendekatan tersebut memang sesuai dan menjadi standar pembelajaran IPA di jenjang SMP MTs.

\section{UCAPAN TERIMA KASIH}

Sebagai bagian akhir dari artikel ini, maka perkenankan penulis menyampaikan terimakasih kepada Promotor bapak Dr. Agus Setiawan; co Promotor ibu Prof. Dr. Liliasari, M.Pd; Dekan FMIPA, UNY bapak Dr. Ariswan; Kaprodi pendidikan IPA, FMIPA, UNY bapak Prof. Dr. Zuhdan K. P. M.Ed.; serta para mahasiswa $S_{1}$ pendidikan IPA FMIPA, UNY semester VI, dimana semua pihak tersebut telah membantu penulis dalam proses penelitian.

\section{DAFTAR PUSTAKA}

American Assosiation for the Advancement of Science. 1993. Bencmarks for Science Literacy. Project 
2061. New York: Oxford University Press.

Carribbean Examination Council. 2007. Integrated Science. Carribbean

Certificate of Secondary Level Competence Curriculum Development Center. 2002. Integrated Curriculum for Secondary School (Curriculum Specification. Science Form 2. Ministry of Education Malaysia

Fogarty, R. 1991. How to Integrated the Curricula. United States of America: IRI/Skylight Publishing. Inc.

Ghufron, Anik. 2007. "Pemutakhiran Kurikulum di Perguruan Tinggi". Cakrawala Pendidikan. Februari, Th XXVI, No. 1.

Manajemen Pendidikan Dasar dan Menengah Direktorat Pembinaan Sekolah Menengah Pertama.

NSTA. 2003. Standards for Science Teacher Preparation. Revised 2003.

Rutherford, F.J. dan Ahlgren, A. 1990. Science for All Americans. New York: Oxfor University Press.

Subali, Bambang. dkk. 2005. "DukunganKurikulum 2004 terhadap Pem- belajaran Pengetahuan Alam Terintegrasi di SMP". Cakrawala Pendidikan. Juni, Th XXIV, No. 2.

Suyono. 2007. "Penerapan Pembelajaran Berdasar Masalah untuk Mengatasi Kesulitan Siswa dalam Mengerjakan Soal Bercirikan Keterampilan Proses". Cakrawala Pendidikan. Juni, Th XXVI, No. 2.

Trefil, J. dan Hazen, R. M. 2004. Standarstandar Guru Pemula untuk SMP/ MTs. Jakarta: Dirjen DIKTI. Departemen Pendidikan Nasional. . 2005. Panduan Pembelajaran IPA Terpadu. Jakarta: Pusat Kurikulum. Balitbang. Departemen Pendidikan Nasional. . 2007. Kurikulum 2002 FMIPA. Departemen Pendidikan Nasional Universitas Negeri Yogyakarta.

2007. The Science: An Integrated Approach. United Stated of America: John Wiley \& Sons, Inc. 2009. Panduan Bimbingan Teknis Model Pembelajaran IPA-IPS Terpadu Sekolah Menengah Pertama. Departemen Pendidikan Nasional. 